\title{
PEMANFAATAN TEKNIK PENGINDERAAN JAUH DAN SISTEM INFORMASI GEOGRAFIS UNTUK MEMANTAU PERUBAHAN PROFIL PANTAI AKIBAT SEDIMENTASI DI MUARA SUNGAI SADDANG KABUPATEN PINRANG, SULAWESI SELATAN
}

\author{
Mudian Paena*) \\ *) Balai Riset Perikanan Budidaya Air Payau, Maros
}

\begin{abstract}
ABSTRAK
Pemantauan perubahan profil pantai akibat pengendapan selama ini sangat sulit dilakukan, selain proses perubahannya sangat lambat juga secara spasial sulit digambarkan. Namun demikian, dengan semakin populernya pemanfaatan satelit penginderaan jauh untuk sumberdaya yang dikombinasikan dengan Sistem Informasi Geografis (SIG) menjadikan pemantauan perubahan profil pantai dengan mudah dapat dilakukan. Penelitian ini bertujuan untuk mengetahui laju perubahan profil pantai akibat pengendapan di sekitar muara Sungai Saddang Kabupaten Pinrang. Bahan yang digunakan pada penelitian ini adalah Citra Landsat7 ETM $^{+}$tahun 2002 dan 2005 dan Rupa Bumi Indonesia (RBI) lembar Pinrang skala 1:50.000. Hasil penelitian menunjukkan bahwa telah terjadi proses sedimentasi yang menyebabkan perubahan profil pantai di sekitar muara Sungai Saddang, perubahan tersebut dikategorikan sangat cepat, mengingat dalam kurun waktu 14 tahun (1991-2005) saja terjadi penambahan daratan seluas 147,04 ha atau rata-rata penambahan daratan sebesar 10,50 ha/tahun; di mana seluas 119,86 ha di bagian selatan dan 27,18 ha di bagian utara muara Sungai Saddang. Peningkatan endapan ini dapat meningkatkan frekuensi banjir yang mempunyai dampak terhadap penurunan produksi tambak sebesar $60 \%-80 \%$
\end{abstract}

KATA KUNCI: penginderaan jauh, SIG, perubahan profil pantai, muara Sungai Saddang

\section{PENDAHULUAN}

Indonesia merupakan kawasan dengan geomorfologi pantai yang khas dan unik. Hal tersebut disebabkan karena Indonesia terletak di atas beberapa lempeng tektonik utama dunia yang saling bersinggungan yaitu Eurasia,
India-Australia, Pasifik, dan Filipina (Ikayati et al., 2001). Berdasarkan asal usul sedimen pesisir dan dasar laut dapat digolongkan sebagai berikut: (1) lithogenous yaitu jenis sedimen yang berasal dari pelapukan batuan dari daratan yang memasuki laut melalui drainase air sungai, (2) biogenaeus yaitu jenis sedimen yang berasal dari organisme laut yang telah mati, (3) hydrogenous yaitu sedimen yang berasal dari komponen kimia yang larut dalam air laut dengan konsentrasi jenuh, (4) cosmogenous yaitu jenis sedimen yang berasal dari ruang angkasa di mana partikel dari benda-benda angkasa ditemukan di dasar laut dan banyak mengandung unsur-unsur besi (Wibisono, 2005). Selain itu, buangan limbah manusia juga merupakan salah satu jenis sedimen. Sedimen lithogenous dan sedimen limbah manusia merupakan kombinasi sedimen yang paling besar pengaruhnya terhadap perubahan profil pantai.

Sedimentasi yang tinggi akan berdampak negatif dan merupakan faktor utama penyebab degradasi sumber daya perikanan (Taurusman et al., 2001). Besarnya sedimentasi yang terjadi di muara Sungai Saddang akan mempengaruhi frekuensi banjir, sekaligus berdampak pada penurunan produksi tambak.

Pemantauan perubahan profil pantai akibat pengendapan selama ini sangat sulit dilakukan, selain proses perubahannya sangat lambat juga secara spasial sulit digambarkan. Namun demikian dengan semakin populernya pemanfaatan satelit penginderaan jauh untuk sumber daya yang dikombinasikan dengan Sistem Informasi Geografis (SIG) menjadikan pemantauan perubahan profil pantai dengan mudah dapat dilakukan. Pemantauan dapat dilakukan dengan menganalisis citra satelit yang perekamannya dilakukan pada waktu yang berbeda (multitemporal). Periode pemantauan dapat dilakukan 10--20 tahun sekali, tergantung dari karakter masing-masing wilayah pesisir.

Pengamatan ini bertujuan untuk mengetahui laju perubahan profil pantai akibat sedimentasi di sekitar muara Sungai Saddang Kabupaten Pinrang. Hasil 
pengamatan ini diharapkan dapat menjadi model pendugaan untuk wilayah pesisir di daerah lain sehingga dapat menekan dampak negatifnya terhadap penurunan produksi tambak.

\section{TINJAUAN UMUM PERUBAHAN PROFIL PANTAI}

Secara umum perubahan bentuk profil pantai, di mana terletak di antara daratan dan lautan selain ditentukan oleh kekerasan batuan (daya resistensi), pola morfologi juga ditentukan oleh tahapan tektoniknya apakah labil atau stabil. Secara geologi bentuk pantai terdiri atas bentuk pantai berundak-undak, terjadi di wilayah pengangkatan aktif dan prosesnya sampai saat ini masih terus berjalan, bentuk pantai terjal selain dikontrol oleh adanya struktur geologi seperti adanya pergeseran dan patahan juga keberadaan batuan dasarnya yang sangat resisten terhadap abrasi gelombang laut. Kemudian bentuk pantai landai, selain dikontrol oleh jenis batuan atasnya yang relatif lunak juga terletak di daerah yang relatif stabil dari kegiatan tektonik atau daerah tingkat pasca tektonik, sehingga proses pengangkutan dan pengendapan berjalan tanpa gangguan kegiatan tektonik. Tipe profil pantai terakhir ini merupakan tipe pantai yang terdapat di sekitar muara Sungai Saddang Kabupaten Pinrang. Dahuri et al. (2001) menyatakan bahwa untuk daerah pesisir dan lautan konsep pembentukan profil pantai berlangsung lebih spesifik, di mana parameter oseanografi seperti pasang surut, ombak, arus laut memegang peran yang dominan dalam pembentukan morfologi pantai.

Tipe profil pantai sekitar muara Sungai Saddang yang nampak sampai saat ini minimal dipengaruhi oleh adanya empat proses yaitu (1) proses endogen namun proses ini sangat kecil mempengaruhi perubahan makro profil pantai di muara Sungai Saddang, demikian pula dengan (2) proses degradasi, yang cukup besar pengaruhnya adalah proses (3) proses agradasi yaitu proses penumpukan material sedimentasi yang berasal dari sungai dan dari laut, sedangkan (4) proses biologik pengaruhnya tidak ada. Proses lain yang juga berinteraksi dengan keempat proses tersebut, dalam banyak hal ikut memberi kontribusi terhadap kecepatan pembentukan profil pantai di sekitar muara Sungai Saddang adalah perubahan pola penggunaan lahan di sekitar Daerah Aliran Sungai (DAS) termasuk penggundulan hutan akan mempercepat erosi dan sedimentasi di sekitar pantai. Namun demikian parameter oseanografi seperti pasang surut, ombak, arus laut juga memegang peranan yang dominan dalam pembentukan morfologi pantai termasuk pantai sekitar muara Sungai Saddang.

\section{PENGAMATAN PROFIL PANTAI MELALUI LANDSAT- 7 ETM}

Perubahan geomorfologi pantai sekitar muara Sungai Saddang terjadi secara terus-menerus dan memberikan gambaran profil pantai yang juga secara terus-menerus mengalami perubahan. Perubahan dapat diamati melalui perekam citra Landsat-7 ETM dalam periode waktu yang berbeda. Secara spasial dapat diamati pada peta (Gambar 1). Perubahan-perubahan tersebut sangat dipengaruhi oleh beberapa faktor namun yang pasti aktivitas manusia sangat mempengaruhi perubahan-perubahan tersebut.

Perubahan profil pantai sekitar muara Sungai Saddang yang diamati adalah perubahan garis pantai di mana hasil analisis citra penginderaan jauh menunjukkan telah terjadi perubahan garis pantai antara tahun 1991 (berdasarkan peta RBI). Perubahan terus terjadi sampai pada tahun 2002 dan 2005 (berdasarkan analisis citra Landsat-7 ETM ${ }^{+}$). Selain garis pantai, juga diamati jenis penggunaan lahan di daratan. Dalam kajian ini, analisis diarahkan untuk mengekstrak jenis penggunaan lahan daerah kajian (analisis digital). Untuk keperluan pengembangan kawasan atau pemodelan lingkungan suatu lahan, data informasi penggunaan lahan atau penutupan lahan terbaru adalah sangat diperlukan (Kushardono, 1999). Selain penggunaan lahan, ekstrak data spasial juga diarahkan pada perubahan profil pantai. Analisis dilakukan dengan mereduksi kanal yang sesuai. Paena et al. (2006) menyatakan reduksi kanal menjadi sangat penting dalam analisis karena akan menentukan variasi warna baik pada citra asli maupun warna pada hasil klasifikasi citra. Kenampakan warna pada citra asli yang dikontrol melalui reduksi kanal akan memberikan kemudahan dalam melakukan visualisasi kenampakan pada lembar citra, sehingga memudahkan mengenali objek atau fenomena yang akan dikaji. Sedangkan tampilan warna hasil klasifikasi akan memberikan kemudahan dalam menentukan batasbatas ekstrim setiap objek atau fenomena yang berbeda dalam sebuah lembar citra. Analisis dilanjutkan secara visual (analisis visual) pada layar komputer atau pada hardcopy, dimaksudkan untuk mengamati secara keseluruhan wilayah yang ada di sekitar muara Sungai Saddang. Selanjutnya dilakukan delineasi citra pada daerah sekitar muara Sungai Saddang untuk menghasilkan poligton digital perubahan profil pantai. Proses delineasi citra dilakukan untuk masing-masing periode perekaman citra.

Perubahan garis pantai tersebut diartikan sebagai perubahan profil pantai, diakibatkan oleh penumpukan material dari proses sedimentasi yang terjadi secara terus-menerus. 


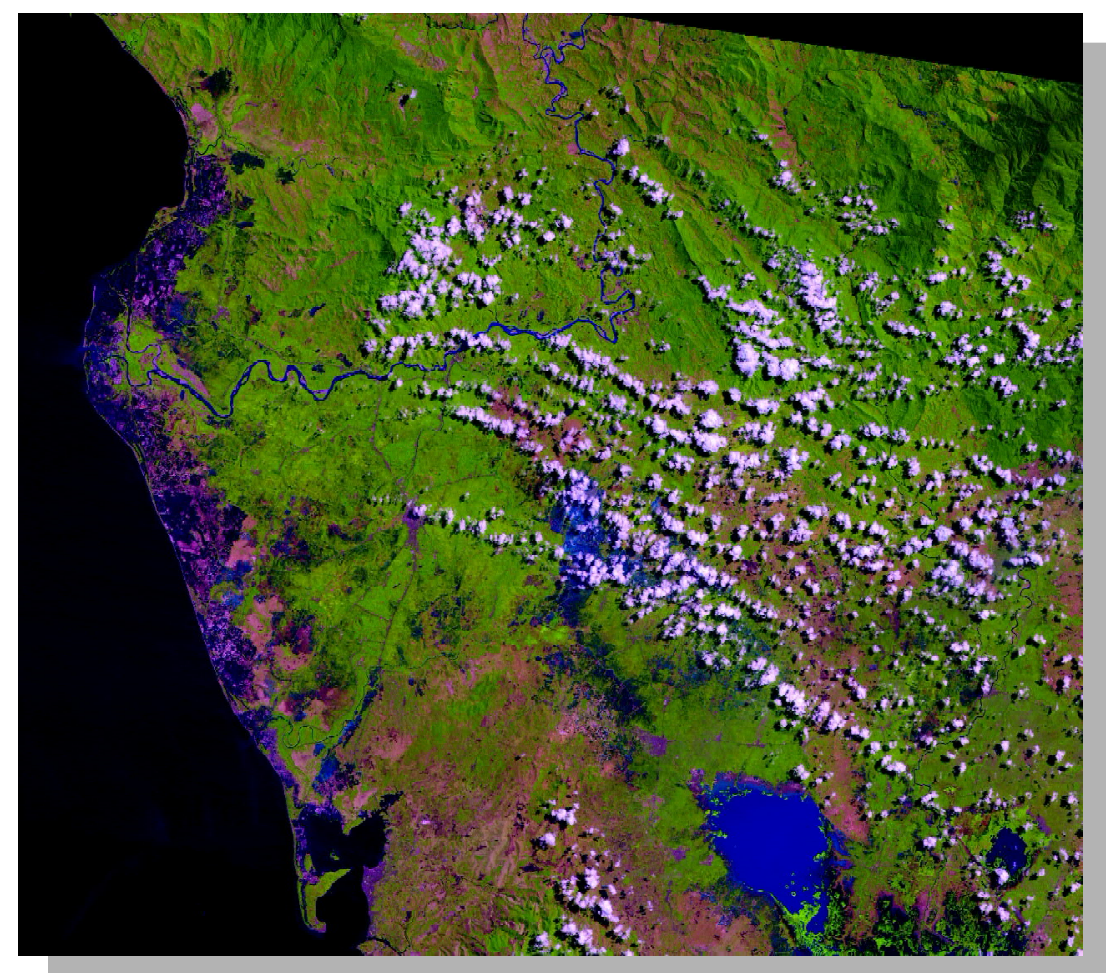

Gambar 1. Citra Landsat-7 ETM+ Kabupaten Pinrang dan aliran Sungai Saddang

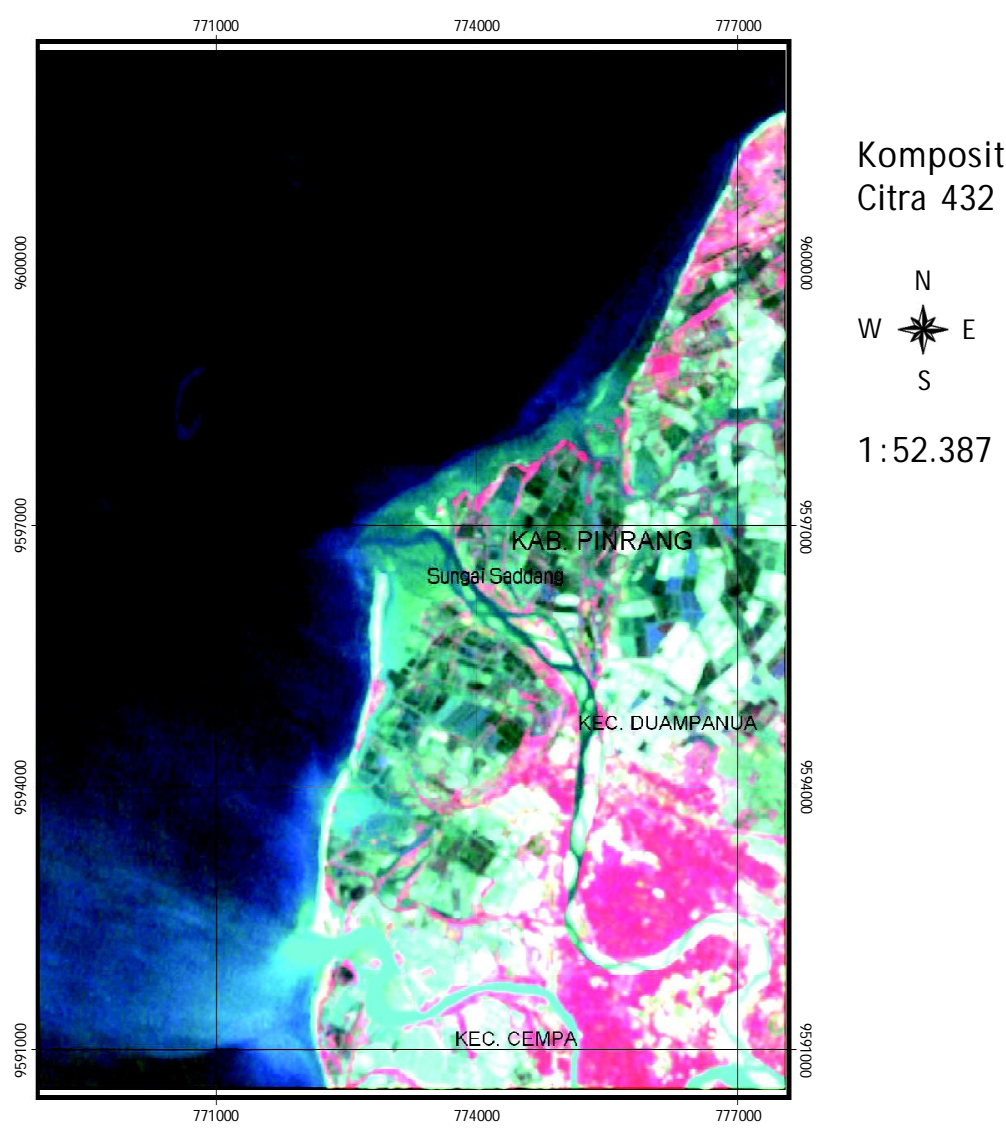

Gambar 2. Peta Citra 2002 kondisi pantai sekitar muara Sungai Saddang Kabupaten Pinrang, Sulawesi Selatan 


\section{DINAMIKA HIDRO-OSEANOGRAFI}

Pentingnya mempelajari dinamika hidro-oseanografi pantai sekitar muara Sungai Saddang seperti ombak karena sangat berpengaruh terhadap perubahan profil pantai pada daerah di mana gelombang pecah (breaker zone) mempunyai energi yang sangat besar untuk menyeret sedimen yang ada di dasar laut menuju arah pantai dan diendapkan hingga merubah profil pantai sebelumnya. Hal ini terjadi secara terus-menerus maka proses perubahan profil pantai juga akan terus berlangsung. Selain ombak, arus yang mengarah ke pantai merupakan penyebab utama lain yang mempengaruhi perubahan profil pantai, berbeda dengan ombak, arus laut mampu membawa sedimen yang mengapung maupun yang terdapat di dasar laut. Sedangkan pasang surut pengaruhnya terhadap perubahan profil pantai sangat kecil dibandingkan dengan ombak dan arus (Wibisono, 2005). Meskipun demikian pasang surut laut yang terjadi ikut mempengaruhi dinamika air di pantai sekitar muara Sungai Saddang. Pergerakan air akibat pasang surut dapat diamati di depan atau di muara Sungai Saddang. Pada saat pasang air sungai mengalir kearah laut di atas massa air laut yang bergerak kearah darat. Pergerakan air laut kearah darat akan mengangkat massa air sungai lebih keatas dan bahkan pada waktu-waktu tertentu seringkali meluap melampaui tanggul alam di sisi kiri kanan sungai. Bersamaan dengan melimpahnya air tersebut, suspensi sedimen akan terbawa serta dan mengendap di luar lembahnya. Sebaliknya pada waktu surut air laut akan bergerak ke laut serta memperlancar aliran sungai yang ada di atasnya. Arus pasang surut yang terjadi umumnya tidak terlalu kuat untuk mengangkat sedimen berbutir kasar kecuali sedimen berbutir halus, tetapi sudah cukup untuk memberikan kontribusi sedimentasi di pantai sekitar muara Sungai Saddang.

\section{SEDIMENTASI DARI DAS SUNGAI SADDANG}

Secara geomorfologi, wilayah pantai muara Sungai Saddang Kabupaten Pinrang merupakan jenis pantai yang stabil dan berbentuk landai. Konsekuensi dari bentuk tersebut menyebabkan wilayah ini sangat aktif terjadi pertumbuhan pantai yang secara langsung akan merubah profil pantai dari tahun-ketahun.

Bentuk sungai radial seperti yang terlihat pada peta juga mempengaruhi kecepatan aliran sungai. Dengan pola aliran sungai yang demikian maka pergerakan aliran sungai mengalami perlambatan saat mendekati muara sungai atau pada tempat-tempat di mana terjadi pembelokan arah alur sungai. Keadaan ini akan menyebabkan material sedimentasi yang berasal dari DAS mempunyai potensi besar untuk diendapkan di muara sungai. Sedangkan volume sedimentasi juga dipengaruhi oleh aktivitas manusia.

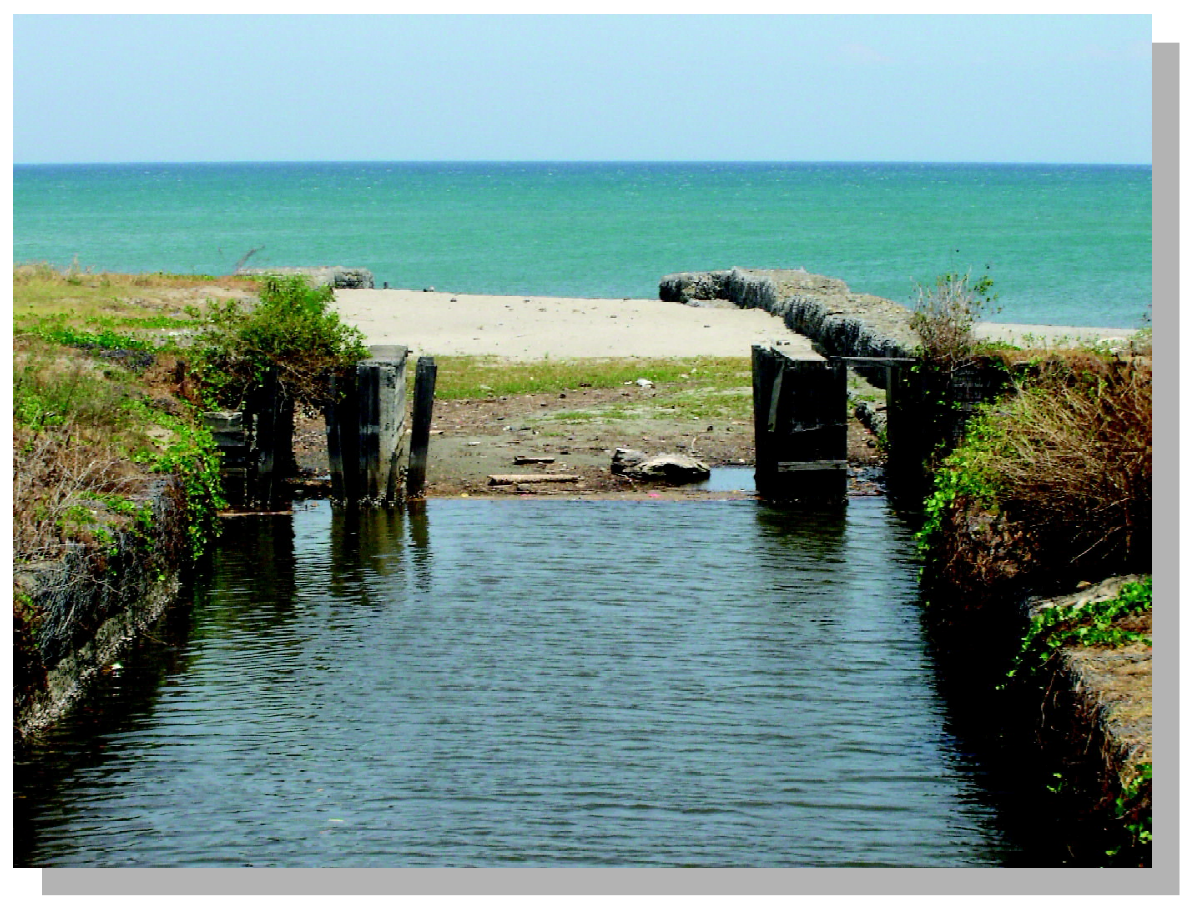

Gambar 3. Pembuatan drainase tambak di Kabupaten Pinrang yang tidak mempertimbangkan secara matang dinamika hidro-oseanografi (Foto: Akhmad Mustafa, 2006) 
Akumulasi dari proses-proses alami dan aktivitas manusia tersebut maka proses sedimentasi menyebabkan perubahan profil pantai di sekitar muara Sungai Saddang, perubahan tersebut dikategorikan sangat cepat, mengingat dalam kurun waktu 14 tahun (1991--2005) saja terjadi penambahan daratan sebesar 10,50 ha/tahun (Tabel 1), sekali pun pada tahun-tahun tertentu penambahan daratan tidak seluas angka tersebut namun pada tahun-tahun tertentu pula terjadi penambahan daratan melebihi angka tersebut, menyebabkan dalam kurun waktu tersebut terjadi penambahan daratan seluas
147,04 ha masing-masing 119,86 ha di bagian selatan dan 27,18 ha di bagian utara.

Berdasarkan laju perubahan profil pantai sekitar muara Sungai Saddang maka pada bagian selatan penambahan daratan lebih aktif sampai 8,56 ha/tahun; sedangkan pada bagian utara hanya mencapai 1,94 ha/tahun. Hal tersebut terjadi diduga karena pola arus sejajar pantai dan arus susur pantai berbeda di dua posisi tersebut. Selain itu, arah muara serta profil pantai sebelumnya juga mempengaruhi keadaan tersebut. Akibatnya profil pantai terus mengalami perubahan mengikuti laju sedimentasi.

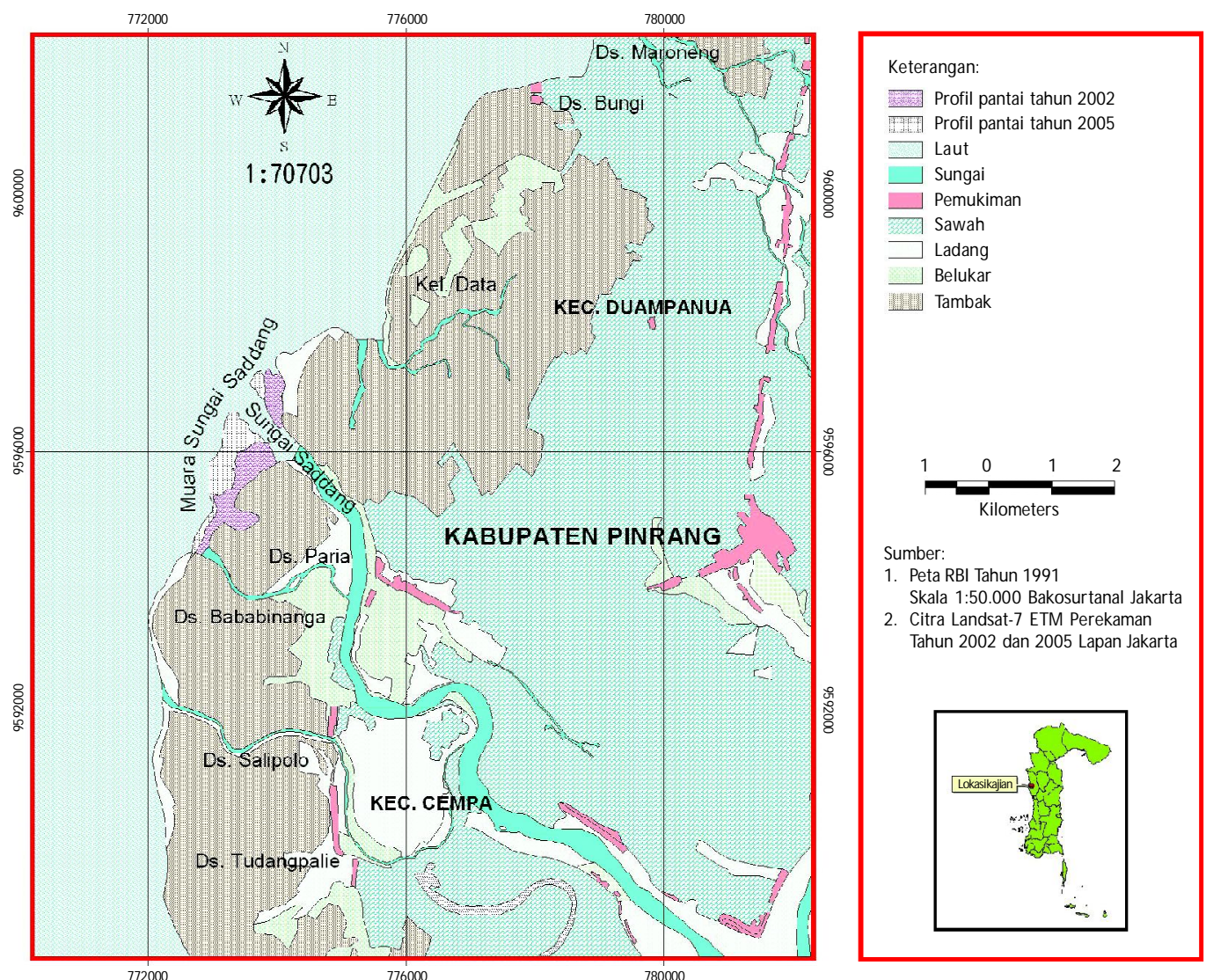

Gambar 4. Peta perubahan profil pantai sekitar muara Sungai Saddang Kabupaten Pinrang, Sulawesi Selatan

Tabel 1. Luas areal sedimentasi pantai sekitar muara Sungai Saddang bagian selatan dan utara pada tahun 2002 dan 2005

\begin{tabular}{cccc}
\hline Tahun & $\begin{array}{c}\text { Bagian Selatan } \\
\text { Sungai Saddang } \\
\text { (ha) }\end{array}$ & $\begin{array}{c}\text { Bagian Utara } \\
\text { Sungai Saddang } \\
\text { (ha) }\end{array}$ & Jumlah (ha) \\
\hline 2002 & 62,13 & 20,88 & 83,01 \\
2005 & 57,73 & 6,30 & 64,03 \\
\hline Total & $\mathbf{1 1 9 , 8 6}$ & $\mathbf{2 7 , 1 8}$ & $\mathbf{1 4 7 , 0 4}$ \\
\hline Pertambahan/tahun & $\mathbf{8 , 5 6}$ ha/tahun & $\mathbf{1 , 9 4}$ ha/tahun & $\mathbf{1 0 , 5 0 ~ h a / t a h u n}$ \\
\hline
\end{tabular}




\section{DAMPAK TERHADAP PRODUKSI TAMBAK}

Tingginya frekuensi banjir yang terjadi di sekitar muara Sungai Saddang selama ini salah satu penyebabnya adalah cepatnya proses sedimentasi di muara tersebut. Adanya penumpukan endapan di depan muara dan menyempitnya aliran sungai akan menghalangi pergerakan air yang menuju ke laut, akibatnya setiap terjadi banjir membutuhkan waktu yang lama untuk surut dan daerah genangan semakin meluas. Meluasnya daerah genangan tersebut menyebabkan semakin banyak pula daerah tambak yang mengalami kerusakan sehingga menyebabkan gagal panen. Kondisi ini menggambarkan bahwa setiap terjadi banjir, secara langsung menurunkan produksi tambak.

Hasil penelusuran data statistik di dinas terkait tidak ditemukan angka-angka yang menunjukkan tingkat penurunan produksi tambak akibat terjadinya banjir selama ini, namun berdasarkan wawancara dengan masyarakat setempat menunjukkan bahwa penurunan produksi tambak dapat mencapai angka 60\%-80\% Hal yang sama juga telah terjadi di perairan Segara Anakan, Cilacap, Jawa Tengah yang mengakibatkan penurunan produksi perikanan, selain itu mengakibatkan pula kapal berukuran lebih dari 30 GT sulit memasuki Pelabuhan Perikanan Samudera Cilacap. Atas problem tersebut dibutuhkan dana sebesar Rp 500 juta per tahun untuk biaya pengerukan (Soesilo \& Budiman, 2006).

\section{KESIMPULAN DAN SARAN}

\section{Kesimpulan}

Dari pengamatan yang telah dilakukan maka dapat disimpulkan:

1. Telah terjadi perubahan profil pantai akibat sedimentasi di sekitar muara Sungai Saddang akibat dari intensifnya sedimentasi.

2. Proses sedimentasi telah menyebabkan terjadinya penambahan luas daratan sekaligus berpengaruh langsung terhadap pembentukan profil pantai yang baru.

3. Sedimentasi yang terjadi sejak tahun 1991--2005 telah menyebabkan penambahan daratan seluas 147,04 ha dalam selang waktu 14 tahun atau rata-rata 10,50 ha/ tahun.

4. Sedimentasi yang terjadi selama ini telah menurunkan produksi tambak di sekitar muara Sungai Saddang sebesar $60 \%-80 \%$

\section{Saran}

Dari hasil pengamatan tersebut, maka pemerintah Kabupaten Pinrang dalam hal ini Dinas Perikanan dan Kelautan sangat diharapkan untuk terus melakukan pemantauan terhadap proses sedimentasi di pantai sekitar muara Sungai Saddang, sekaligus mengambil langkahlangkah strategis, mengingat proses tersebut telah memberikan dampak negatif pada aktivitas di sekitar pantai tersebut dan terhadap DAS Sungai Saddang.

\section{DAFTAR PUSTAKA}

Dahuri, R., J. Rais, S.P. Ginting, dan M.J. Sitepu. 2001. Pengelolaan Sumberdaya Wilayah Pesisir dan Lautan Secara Terpadu, Cetakan Kedua Edisi Revisi, Pradnya Paratama, Jakarta. 18 pp.

Ikayati, Y., Hanggarawati, S.H. Puji, P. Hening, H. Hendrati, dan S. Budiman. 2001. Terumbu Karang di Indonesia. Maspitek dan Ristek. Jakarta. 1 pp.

Kushardono, D. 1999. Klasifikasi penutup/penggunaan lahan dari data inderaja. Dalam Suharmanto, F. Tjinda, S. Yulmontoro, I.L. Arisdyo, R. Ginting, dan A. Effendi (Eds.), Pengantar Teknologi, Aplikasi Penginderaan Jauh Satelit dan Sistem Informasi Geografi. Lembaga Penerbangan dan Antariksa Nasional dan Badan Pengkajian dan Penerapan Teknologi, Jakarta. p. 167184.

Paena, M., A. M ustafa, Hasnawi, dan Rahmansyah. 2006. Validasi Luas Lahan Tambak Di Kabupaten Pinrang Provinsi Sulawesi Selatan dengan Menggunakan Teknologi Penginderaan Jauh dan Sistem Informasi Geografis. J. Ris. Akuakultur. 2(3): 329-340.

Soesilo, I. dan Budiman. 2006. IPTEK Menguak Laut Indonesia. PT Sarana Komunikasi Utama (SKU). Bogor. p. $521-522$.

Taurusman, A.A., R. Dahuri, dan T. Kusumastono. 2001. Model Sedimentasi dan Daya Dukung Lingkungan Segara Anakan untuk Kegiatan Budidaya Udang. Jurnal Pesisir dan Lautan (Indonesian Journal of Coastal and Marine Resources). PKSPL-IPB. Bogor. 4(2): 50-62.

Wibisono, M.S. 2005. Pengantar Ilmu Kelautan. Grasindo. Jakarta. 30 pp. 